\title{
The Role of Ki Hadjar Dewantara's Personal Branding and University Branding on Brand Image Universitas Tamansiswa Padang
}

\author{
Berri Brilliant Albar ${ }^{1}$, Sepris Yonaldi ${ }^{2}$, Delvi $^{3}$ \\ \{berribet@gmail.com ${ }^{1}$, seprisyonaldi@gmail.com ${ }^{2}$ \} \\ ${ }^{1}$ Universitas Andalas, Padang, Indonesia \\ ${ }^{2,3}$ Universitas Taman Siswa, Padang, Indonesia
}

\begin{abstract}
The purpose of this study is to determine and analyze the role of personal branding Ki. Hadjar Dewantara and university branding partially and simultaneously on Tamansiswa Padang brand image. The research method used descriptive quantitative. The sampling technique was accidental sampling with survey methods and using an instrument questionnaire on 100 respondents as samples. The data analysis technique used multiple linear regression, t-test, F-test, and coefficient of determination. Based on the results of the partial and simultaneous personal branding variables Ki. Hadjar Dewantara and university branding have a significant effect on Universitas Tamansiswa Padang's brand image with a significant value $<0.05$. While the coefficient of determination is found in the adjusted R-Square value of $55.1 \%$.
\end{abstract}

Keywords: Personal Branding, University Branding, and Brand Image.

\section{Introduction}

Suwardi Suryaningrat or better known as Ki Hadjar Dewantara was born on May 2, 1889 in Yogyakarta. He came from the Yogyakarta's royal family. His father's name was Kanjeng Pangeran Harjo Surjaningrat, Kanjeng Gusti's son Prince Hadipati Hardjo Surjosasraningrat whose title was Sri Paku Alam III. He was an activist for the Indonesian independence movement, columnist, politician, and education pioneer for Indonesian natives from the Dutch colonial era. He is the founder of Tamansiswa College, an educational institution that provides opportunities for ordinary natives to be able to obtain the education as well as the prijajis and the Dutch people. Once he was exiled to the Netherlands by the Dutch government from September $6^{\text {th }}, 1913$ to September $5^{\text {th }}, 1919$, because of his scathing criticism "Als Ik Eens Nederlander Was" (if I were a Dutchman) of the Dutch East Indies government at that time.

Because of his dedication and great achievements in education, he became the first Indonesian minister of education on August $19^{\text {th }}, 1945$-November $14^{\text {th }}, 1945$ in the Soekarno era. He died on April $26^{\text {th }}, 1959$, and honored as a National Hero of Indonesia by Indonesia's first president, Soekarno, on November $28^{\text {th }}, 1959$. He is now remembered as the Father of Indonesian Education. And the government of the Republic of Indonesia then set his birthday, May $2^{\text {nd }}$ as National Education Day. 
Personal Branding is a very important thing, and the main requirement to success. Whether an entrepreneur, executive, employee, student, or official, needs a good personal branding of a person, and not everyone has good personal branding. Brand Image is the way people think about a brand abstractly in their thinking, even when they think about it, they don't deal directly with the product. Building a positive brand image can be achieved with a strong marketing program for the product, which is unique and has advantages that are highlighted, which distinguishes it from other products. A good combination of supporting elements can create a strong brand image for consumers.

Universitas Tamansiswa Padang is one of the Private Universities in Padang (West Sumatera, Indonesia) established in 1987 founded by Ki. Yusuf Nur, based in Yogyakarta under the auspices of the Noble Council of Tamansiswa Unity. Viewed in terms of the location of the University is very strategic because it is located in the center of the city of Padang which is located on Jl. Tamansiswa No. 9 Padang, 25138. All study programs are accredited by BAN PT. Universitas Tamansiswa Padang consists of 3 faculties namely the Faculty of Agriculture, the Faculty of Law, and the Faculty of Economics. In accordance with the increasingly rapid development of universities in the city of Padang University Tamansiswa must compete in the face of a very tight competition where not only compete with fellow Private Universities but also with State Universities.

This study will examine the extent of the role of personal branding Ki. Hadjar Dewantara and university branding on brand Image of Universitas Tamansiswa Padang. Having Ki Hadjar Dewantara with a good personal branding can not be ascertained to have an effect on the Tamansiswa Padang's brand image, because it is in accordance with the development of the era in which the next generation of new nation's birth is likely to not recognize the figure of an educational hero Ki. Hadjar Dewantara. In addition there are still some people who do not understand the cloud or know at all who and what the role of Ki. Hadjar Dewantara until the birth of Tamansiswa.

Based on the description above becomes the focus of researchers whether "The Role of Ki Hadjar Dewantara's Personal Branding and University Branding Role on Brand Image Universitas Tamansiswa Padang" will have a positive or negative effect. Based on the problems that have been identified above, this study aims to determine the extent of the Role of Personal Branding Ki. Hadjar Dewantara and University Branding on Brand Image of Universitas Tamansiswa Padang.

\section{Literature Review}

\subsection{Personal Branding}

According to Lair, Sullivan, and Cheney (2005) explains "Personal Branding is a process where you are seen as a brand by your target market." Another expert, Montoya (2008) explained that "personal branding is an image the strong and clear in your mind's mind about yourself. Three important aspects of the personal brand are you, promises, and relationships. There are three main components incorporated into one, which determines the strength of a personal branding (McNally and Speak, 2011) strong brands are distinctive brands, brands that are relevant and brands that are consistent.

\subsection{University Branding}

In the study of Bennet and Ali Choudhury (2009), a university brand has carried out three main dimensions: agreement, quiddity, symbolic, and externally related. Covenant is a 
promise given by the brand, while quality spurs the brand, and symbolic and external representations are visual descriptions that influence attitudes toward the brand.

\subsection{Brand Image}

Brand image is a description of the association and consumer confidence in certain brands. According to Kotler (2012), brand image is a number of beliefs about the brand. According to Aaker, brand image is considered as "how the brand is perceived by consumers". With regard to perception. Brand Imagination as a set of beliefs, ideas, and impressions that a person has towards a brand is largely determined by the brand image, and brand image is a prerequisite for a strong brand. Measurement of brand image can be based on the basic indicators Kotler and Keller (2016) are strength, uniqueness and favorable (brand ability to be easily remembered).

\subsection{Research Hypothesis}

H1 Personal Branding expectancy positively and significantly influences the Brand Image

$\mathrm{H} 2$ University Branding expectancy positively and significantly influences the Brand Image.

H3 Personal Branding and University Branding expectancy simultaneously positive and significantly influences the Brand Image.

Based on literature reviews and the development of hypotheses, we then arranged the theoretical framework for this study which is shown in the figure 1 below

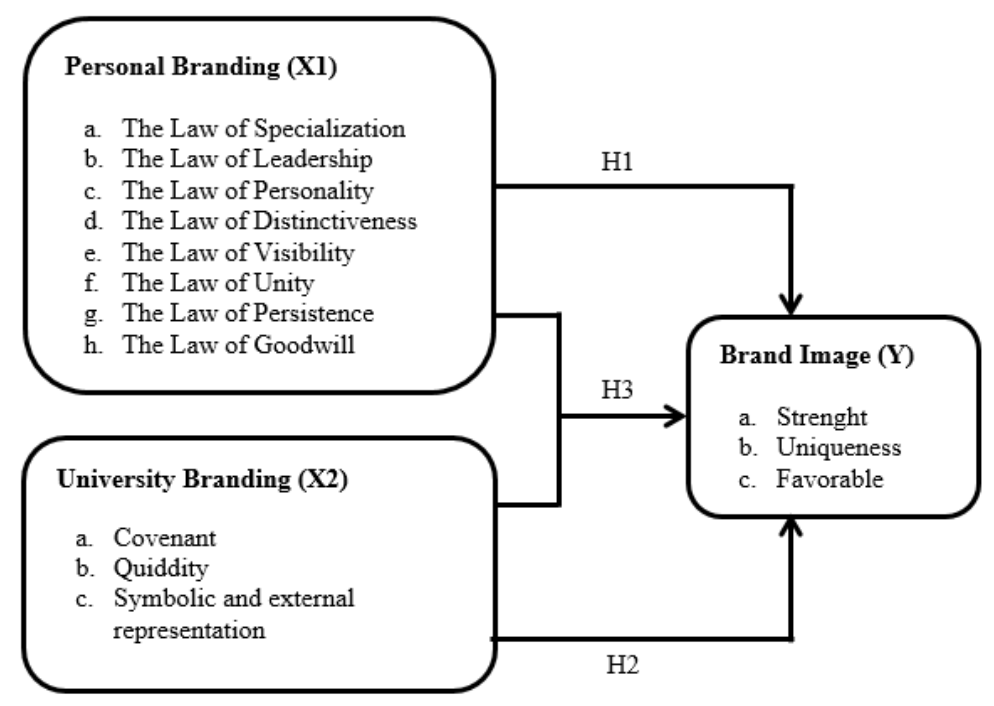

Fig. 1. Conceptual Framework

\section{Research Method}

This study uses a quantitative research method approach, is a method based on positivism, the method used to examine certain populations or samples sampling technique is usually 
carried out with the calculation of certain sample techniques that are suitable for quantitative/statistical data collection with the aim of testing established hypotheses.

\section{Population and Samples}

The population in this study were active students of Universitas Tamansiswa Padang in $2016 / 2017$ as many as 1,336 people. There is also a way of taking data using the simple random sampling, which is a sampling technique based on coincidence, anyone who accidentally meets a researcher who is used as a sample if someone who happens to be suitable as a source of data. To determine the sample size in this study using the Slovin formula as follows:

$$
\begin{aligned}
n & =\frac{N}{1+N e^{2}} \\
n & =\frac{1.336}{1+1.336(0,10)^{2}} \\
n & =99,92
\end{aligned}
$$

Based on calculations using the Slovin formula above, the number of samples in this study were 100 students from Universitas Tamansiswa Padang.

\section{Result}

\subsection{Multiple Linear Regression Analysis}

Multiple linear regression analysis is used to determine the direction of the relationship between the independent variable and the dependent variable whether each independent variable has a positive or negative effect, and to predict the value of the dependent variable if the value of the independent variable has increased or decreased. Based on the multiple regression test can be seen in Table 1 below:

Table. 1. Multiple Linear Regression Test Results

\begin{tabular}{ccccccc}
\hline \multicolumn{1}{c}{ Coefficients $^{\mathbf{a}}$} & \multicolumn{2}{c}{$\begin{array}{l}\text { Unstandardized } \\
\text { Coefficients }\end{array}$} & $\begin{array}{c}\text { Standardized } \\
\text { Coefficients }\end{array}$ & & & \\
\cline { 2 - 4 } Model & \multicolumn{2}{c}{ B } & Std. Error & Beta & & Sig. \\
\hline (Constant) & 4.464 & 1.917 & & 2.329 & .022 \\
Personal_Branding & .169 & .034 & .458 & & 5.005 & .000 \\
University_Branding & .374 & .095 & .359 & & 3.924 & .000 \\
a. Dependent Variable: Brand_Image & & & & & \\
\hline
\end{tabular}

Source: Primary data processed, 2017

Based on data analysis using the SPSS 20 program, the regression equation results are obtained as follows:

$\mathrm{Y}=4,464+0,169 \mathrm{X} 1+0,374 \mathrm{X} 2+\mathrm{e}$

1. The constant value is $=4,464$ meaning that if there is no change in the personal branding and university branding variables (the values of X1 and X2 are 0) then the brand image of Universitas Tamansiswa Padang already exists at 4,464 units. 
2. Personal branding regression coefficient value $=0.169$ means that if the personal branding variable (X1) increases by 1 (unit) assuming the university branding variable (X2) and the constant (a) is 0 (zero), then the brand image of Tamansiswa Padang University increases amounting to 0.169 units.

3. University branding regression coefficient value $=0.374$ means that if the university branding variable (X2) increases by 1 (unit) assuming the personal branding variable (X1) and the constant (a) is 0 (zero), then the brand image of Tamansiswa Padang University increases amounting to 0.374 units.

\section{2 t test (Partial)}

The $t$ test is a test carried out to determine the effect of an independent variable on the dependent variable individually (separate). Based on the $t$ test performed can be seen in Table 2 below:

Tabel 2. t-test Results (Partial)

\begin{tabular}{|c|c|c|c|c|c|}
\hline \multirow[t]{3}{*}{ Coefficients $^{\mathrm{a}}$} & & & & & \\
\hline & \multicolumn{2}{|c|}{$\begin{array}{l}\text { Unstandardized } \\
\text { Coefficients }\end{array}$} & \multirow{2}{*}{$\begin{array}{c}\begin{array}{c}\text { Standardized } \\
\text { Coefficients }\end{array} \\
\text { Beta }\end{array}$} & \multirow[b]{2}{*}{$\mathrm{t}$} & \multirow[b]{2}{*}{ Sig. } \\
\hline & $\mathrm{B}$ & Std. Error & & & \\
\hline (Constant) & 4.464 & 1.917 & & 2.329 & .022 \\
\hline Personal_Branding & .169 & .034 & .458 & 5.005 & .000 \\
\hline University_Branding & .374 & .095 & .359 & 3.924 & .000 \\
\hline \multicolumn{6}{|c|}{ a. Dependent Variable: Brand_Image } \\
\hline
\end{tabular}

Personal branding variable (X1) has a positive and significant effect on the brand image of Universitas Tamansiswa Padang, because the significant value produced is $0,000<0.05$ while the value of $\mathrm{t}$ table $\mathrm{df}=\mathrm{n}-\mathrm{k}=100-3=97(1,660)$. This means that the value of $\mathrm{t}$ count $>\mathrm{t}$ table (5.005> 1.660) then Ho is rejected and H1 is accepted. This means that Hypothesis 1 in this study (personal branding variable) is accepted.

University branding variable (X1) influences positively and significantly on the brand image of Universitas Tamansiswa Padang, because the significant value produced is 0,000 $<0.05$ while the value of $\mathrm{t}$ table $\mathrm{df}=\mathrm{n}-\mathrm{k}=100-3=97(1,660)$. This means that the value of $\mathrm{t}$ arithmetic $>\mathrm{t}$ table $(3,924>1,660)$ then Ho is rejected and $\mathrm{H} 2$ is accepted. This means that Hypothesis 2 in this study (university branding variables) can be accepted.

\subsection{F Test}

The F-test can be used to evaluate the effect of all independent variables on the dependent variable. The statistical $F$ value can thus be used to evaluate the hypothesis that there are no independent variables that explain variations in $\mathrm{Y}$. Based on the $\mathrm{F}$ test performed can be seen in Table 3 below. 
Table 3. F Test Results (Simultaneous)

\begin{tabular}{|c|c|c|c|c|c|c|}
\hline \multicolumn{7}{|c|}{ ANOVA $^{b}$} \\
\hline Model & & Sum of Squares & Df & Mean Square & $\mathrm{F}$ & Sig. \\
\hline \multirow[t]{3}{*}{1} & Regression & 469.036 & 2 & 234.518 & 61.770 & $.000^{\mathrm{a}}$ \\
\hline & Residual & 368.274 & 97 & 3.797 & & \\
\hline & Total & 837.310 & 99 & & & \\
\hline \multicolumn{7}{|c|}{ a. Predictors: (Constant), University_Branding, Personal_Branding } \\
\hline \multicolumn{7}{|c|}{ b. Dependent Variable: Brand Image } \\
\hline
\end{tabular}

Based on the test results in the table above can be seen in the calculated $\mathrm{F}$ value of 61.770 with the value Ftabeldf $1=\mathrm{k}-1(3-1=2)$, df $2=\mathrm{n}-\mathrm{k}(100-3=97)$ is 3.09 so the value of Fcount $>$ F-table or $61,770>3.09$ and a significant level of $0.000<0.05$ then Ho is rejected and $\mathrm{H} 3$ is accepted so that it can be concluded that the personal branding variable (X1) and university branding (X2) simultaneously have a significant effect on the brand image of Universitas Tamansiswa Padang.

\subsection{Test Coefficient of Determination}

Tabel 4. Coefficient Determination Test Results

\begin{tabular}{|c|c|c|c|c|c|c|c|c|c|}
\hline \multicolumn{10}{|c|}{ Model Summary } \\
\hline \multirow[b]{2}{*}{ Model } & \multirow[b]{2}{*}{$\mathrm{R}$} & \multirow[b]{2}{*}{$\begin{array}{c}\mathrm{R} \\
\text { Square }\end{array}$} & \multirow[b]{2}{*}{$\begin{array}{l}\text { Adjusted } \\
\text { R Square }\end{array}$} & \multirow{2}{*}{$\begin{array}{l}\text { Std. } \\
\text { Error of the } \\
\text { Estimate }\end{array}$} & \multicolumn{5}{|c|}{ Change Statistics } \\
\hline & & & & & $\begin{array}{l}\text { R Square } \\
\text { Change }\end{array}$ & $\begin{array}{c}\text { F } \\
\text { Change }\end{array}$ & df1 & $\mathrm{df} 2$ & $\begin{array}{r}\text { Sig. F } \\
\text { Change }\end{array}$ \\
\hline 1 & $.748^{\mathrm{a}}$ & .560 & .551 & 1.948 & .560 & 61.770 & 2 & 97 & .000 \\
\hline
\end{tabular}

Source: Primary data processed, 2017

Based on Table 4 it can be seen that the coefficient of determination is found in the Adjusted R-Square value of 0.551 . This means that the strength of the relationship of the independent variable to the dependent variable is only $55.1 \%$ while the remaining $44.9 \%$ is explained by other variables not examined in this study, such as consumer behaviour, marketing mix, and external environment.

\subsection{Discussion}

The personal branding variable is proven that positively and significantly influences the brand image of Tamansiswa Padang University. This is evidenced by the significant value of $0,000<0.05$, while the value of tcount $>$ t-table $(5.005>1,660)$, then Ho is rejected and $\mathrm{H} 1$ is accepted. From the results of this study, it can be concluded that personal branding using the law of specialization, the law of leadership, the law of personality, the law of distinctiveness, the law of visibility, the law of unity, the law of persistence and the of goodwill, can enhance the brand image of Universitas Tamansiswa Padang, this can be known from the highest assessment of the existing personal branding variable indicators in the law of leadership, we know that Ki. Hadjar Dewantara exemplary leader with the concept of the trilogy in 
developing education (Ing Ngarso Sung Tulado (In front of an example), Ing Madiomangun Karso (While giving guidance), Tut Wuri Handayani (Behind giving encouragement) and Ki. Hadjar Dewantara exemplary leader in leading Tamansiwa and as Indonesia's teaching minister, which means having good leadership attitudes and being able to set an example in the development of education, it can provide a good brand image for the Universitas Tamansiswa Padang.

The variable of university branding is proven to have a positive and significant effect on the brand image of Tamansiswa Padang University. This is evidenced by the significant value of $0,000<0.05$, while the value of $t$ arithmetic $>t$ table $(3,924>1,660)$ then Ho is rejected and $\mathrm{H} 2$ is accepted. Based on these results it can be concluded that university branding can improve the brand image of Universitas Tamansiswa Padang, this is caused by covenant, quiddity, symbolic and external representation indicators, this can be known from the highest assessment of university branding variable indicators contained in symbolic and external representation because Padang Tamansiswa University has a good aesthetic logo and the name Tamansiswa University has an attractive appearance with a dominant green color. This means that by providing an attractive logo and appearance, students can provide an assessment of the University of Tamansiswa Padang so that the brand image of Tamansiswa Padang University becomes more enhanced.

Personal branding variables (X1) and university branding (X2) together have a positive and significant influence on the brand image of Universitas Tamansiswa Padang, this can be proven by $\mathrm{F}$ arithmetic $>\mathrm{F}$ table or $61,770>3.09$ and a significant level of $0,000<0.05$, then Ho is rejected and H3 is accepted so it can be concluded that the personal branding variable (X1) and university branding (X2) simultaneously have a significant effect on the brand image of Tamansiswa Padang University by $55.1 \%$. From the test results it can be interpreted that with good personal branding and university branding, the Universitas Tamansiswa Padang is famous for its history which was founded by Ki. Hadjar Dewantara and the name Unitas Padang are quite easy to remember by students and the community.

\section{Summary}

1. Personal branding variable has a positive and significant effect on the brand image of Tamansiswa Padang University.

2. University branding variable influences positively and significantly on the brand image of Tamansiswa Padang University.

3. Simultaneously there is a positive and significant effect between personal branding and university branding variables on the brand image of Tamansiswa University, Padang.

\section{References}

[1] Bennett, R. dan Ali-Choudhury, R. (2009). Prospective students' perceptions of university brands: an empirical study. Journal of Marketing for Higher Education, 19 (1), 85-107.

[2] Kotler, 2012. Stategic Brand Manajemen, Managing Brand Equity:Second Edition, Person Prentice Hall, New Jersey.

[3] Kotler, P. and Keler, K.L. 2016, Marketing Management $15^{\text {th }}$ edition. Pearson Prentice Hall, New Jersey

[4] Lair, Sullivan, and Cheney (2005). Marketization and the Recasting of the Professional Self: The Rhetoric and Ethics of Personal Branding. Sage Journals. 
[5] Montoya, (2008). The Brand Called You: Make Your Business Stand Out in a Crowded Marketplace (paperback). United States of America: McGraw-Hill.

[6] McNally, 2011.Be Your Own Brand: A Breakthrough Formula for Standing Out from the Crowd. Berrett-Koehler Publishers 